\title{
$n$-Butanol production from sucrose and sugarcane juice by engineered Clostridium tyrobutyricum overexpressing sucrose catabolism genes and adhE2
}

Jianzhi Zhang ${ }^{1,2}$, Le Yu ${ }^{2}$, Meng Lin $^{3}$, Qiaojuan Yan ${ }^{1}$, Shang-Tian Yang ${ }^{2}$,*

${ }^{1}$ Bioresource Utilization Laboratory, College of Engineering, China Agricultural University, Beijing 100083, PR China

${ }^{2}$ William G. Lowrie Department of Chemical and Biomolecular Engineering, The Ohio State University, 151 West Woodruff Ave., Columbus, Ohio 43210, USA

${ }^{3}$ Bioprocessing Innovative Company, 4734 Bridle Path Ct., Dublin, OH 43017, USA

*Corresponding author

Shang-Tian Yang. Phone: 614-292-6611; Fax: 614-292-3769; Email: yang.15@osu.edu

Submitted to Bioresource Technology 


\section{$1 \quad$ Abstract}

The production of $n$-butanol from sugarcane juice by metabolically engineered Clostridium tyrobutyricum $\mathrm{Ct}(\Delta \mathrm{ack})$-pscrBAK overexpressing scr operon genes (scrB, scrA, and $s c r K)$ for

4 sucrose catabolism and an aldehyde/alcohol dehydrogenase gene (adhE2) for butanol

5 biosynthesis was studied with corn steep liquor (CSL) as a low-cost nitrogen source. In free cell

6 fermentation, butanol production of $\sim 16 \mathrm{~g} / \mathrm{L}$ at a yield of $0.31 \pm 0.02 \mathrm{~g} / \mathrm{g}$ and productivity of 0.33

$7 \pm 0.02 \mathrm{~g} / \mathrm{L} \cdot \mathrm{h}$ was obtained from sucrose and yield of $0.24 \pm 0.02 \mathrm{~g} / \mathrm{g}$ and productivity of $0.30 \pm$

$8 \quad 0.01 \mathrm{~g} / \mathrm{L} \cdot \mathrm{h}$ from sugarcane juice containing sucrose, glucose and fructose. The fermentation was

9 also studied in a fibrous bed bioreactor $(\mathrm{FBB})$ operated in a repeated batch mode for 10

10 consecutive cycles in 10 days, achieving an average butanol yield of $0.21 \pm 0.02 \mathrm{~g} / \mathrm{g}$ and

11 productivity of $0.53 \pm 0.05 \mathrm{~g} / \mathrm{L} \cdot \mathrm{h}$ from sugarcane juice, demonstrating its long-term stability

12 without applying the antibiotic selection pressure.

14 Keywords: Butanol; Clostridium tyrobutyricum; fibrous bed bioreactor; metabolic engineering;

15 sucrose catabolism; sugarcane juice

16 


\section{Introduction}

In recent years, biological production of $n$-butanol as a renewable substitute of gasoline has attracted large attention for its higher energy density and superior fuel properties compared to ethanol (Zhao et al., 2013). However, butanol production by solventogenic clostridia in acetone-butanol-ethanol (ABE) fermentation suffered from low productivity, yield, and product titer (Zhao et al., 2013). Consequently, the high production cost of biobutanol impedes its industrial application (Green et al., 2011). Extensive efforts have been made to improve ABE fermentation by metabolic engineering of solventogenic clostridia (Cho et al., 2015;

\section{Lütke-Eversloh, 2014; Xu et al., 2015; Zheng et al., 2015) and process optimization including} applying in situ butanol separation to reduce butanol inhibition (Lu et al., 2013; Xue et al., 2012;

2013 ; 2014; 2016) and using low-cost processing wastes or byproducts (Lu et al., 2012; Shao et al., 2015) and lignocellulosic biomass such as agricultural residues (Bellido et al., 2015; Jang et al., 2012). Although extensive work has been focused on using cellulosic feedstocks for biofuels production (Kumar et al., 2013a; Wang et al., 2014; Yang et al., 2015), it is difficult and expensive to hydrolyze cellulosic materials to fermentable sugars and the resulting hydrolysate containing acids and phenolic compounds derived from carbohydrate and lignin degradation are toxic to cells and severely inhibit alcohol production in ABE fermentation (Jang et al., 2012; Liu et al., 2015). Much more research and development efforts are still required for using lignocellulosic biomass hydrolysates as substrates for industrial biobutanol production (Wang et al., 2014).

1 On the other hand, sucrose-based substrates, such as sugarcane juice and cane molasses, are 
easier to use in fermentation and cheaper than glucose and starch-based feedstocks such as corn and cassava (Filho et al., 2011; Kumar et al., 2013b; Wei et al., 2017). Although sugarcane juice and cane molasses have been used in ABE fermentation (Jiang et al., 2014; Ni et al., 2012), its economic viability is limited by the relatively low product titer, yield and productivity with conventional solventogenic clostridia (Mariano et al., 2013). Previously, we have engineered Clostridium tyrobutyricum, an anaerobic bacterium naturally producing butyrate as the main product, to overexpress a bifunctional aldehyde/alcohol dehydrogenase ( $a d h E 2)$ for butanol production (Yu et al., 2011). The mutant was able to produce butanol at a high titer, yield and productivity from glucose (Du et al., 2015), but not sucrose due to lacking of genes required for sucrose catabolism in its genome (Lee et al., 2016).

In the present study, three genes in the $s c r$ operon, $s c r B, s c r A$, and $s c r K$, encoding sucrose 6-phosphate hydrolase, Enzyme II of the sucrose phosphoenolpyruvate (PEP)-dependent phosphotransferase system (PTS), and fructokinase, respectively, and adhE2 were cloned from

Clostridium acetobutylicum ATCC 824 and introduced into C. tyrobutyricum ( $\triangle$ ack), which had its acetate kinase gene (ack) partially knocked out (Liu et al., 2006). The mutant $\mathrm{Ct}(\Delta \mathrm{ack})$-pscrBAK was able to use sucrose, along with glucose and fructose, present in sugarcane juice to produce butanol as the main product. The fermentation kinetics with sucrose and sugarcane juice, respectively, as carbon source and corn steep liquor (CSL) as a low-cost supplemental nitrogen source (Wischral et al., 2016), was studied in free-cell fermentation. Furthermore, the mutant was also studied in a fibrous bed bioreactor (FBB), which has previously been shown to give higher butanol productivity due to higher cell density and 
tolerance to butanol toxicity (Huang et al., 2004; Jiang et al., 2014), operated in a repeated batch mode with media without the antibiotic for plasmid selection, demonstrating its stability and industrial applicability for $n$-butanol production from sugarcane juice.

\section{Materials and methods}

\subsection{Bacterial strain and culture media}

The engineered strain $C$. tyrobutyricum $\mathrm{Ct}(\Delta \mathrm{ack})$-pscrBAK overexpressing Clostridium acetobutylicum 824 adhE2 and scr operon (scrB, scrA, and scrK) genes was used for butanol production from sucrose in this study. To obtain $\mathrm{Ct}(\Delta \mathrm{ack})$-pscrBAK, the plasmid pscrBAK (see

Figure S1 in supplemental materials) was transformed into C. tyrobutyricum ( $\triangle a c k)$ by conjugation following the previously described method (Yu et al., 2012). Positive transformants were selected on CGM agar plates containing $45 \mu \mathrm{g} / \mathrm{mL}$ thiamphenicol and $250 \mu \mathrm{g} / \mathrm{mL}$ cycloserine, confirmed by colony PCR screening and plasmid extraction, and maintained as a cell suspension in $15 \%(\mathrm{v} / \mathrm{v})$ sterile glycerol and stored at $-80{ }^{\circ} \mathrm{C}$. The seed culture for fermentation studies was prepared by inoculating $200 \mu \mathrm{L}$ of the stock with $20 \mathrm{~g} / \mathrm{L}$ glucose and $30 \mu \mathrm{g} / \mathrm{mL}$ thiamphenicol. The CGM medium contained (g/L): 1.0 trace minerals (Zhu and Yang, 2003). Unless otherwise noted, the medium for sucrose fermentation contained (g/L): 60 sucrose, $3\left(\mathrm{NH}_{4}\right)_{2} \mathrm{SO}_{4}, 1.5 \mathrm{~K}_{2} \mathrm{HPO}_{4}, 0.6 \mathrm{MgSO}_{4} \cdot 7 \mathrm{H}_{2} \mathrm{O}, 0.03$ culture into a serum bottle containing $50 \mathrm{~mL}$ Clostridial Growth Medium (CGM) supplemented $\mathrm{K}_{2} \mathrm{HPO}_{4} \cdot 3 \mathrm{H}_{2} \mathrm{O}, 0.5 \mathrm{KH}_{2} \mathrm{PO}_{4}, 2\left(\mathrm{NH}_{4}\right)_{2} \mathrm{SO}_{4}, 0.1 \mathrm{MgSO}_{4} \cdot 7 \mathrm{H}_{2} \mathrm{O}, 2$ yeast extract, 4 tryptone and $\mathrm{FeSO}_{4} \cdot 7 \mathrm{H}_{2} \mathrm{O}, 350 \mu \mathrm{M}$ methyl viologen (MV), and $40 \mathrm{~g} / \mathrm{L}$ corn steep liquor (CSL, $~ 50 \%$ w/w 
solids), which was obtained from a corn wet-milling plant (Ohio, USA). MV was used as an artificial electron carrier to increase intracellular NADH availability for butanol biosynthesis (Du et al., 2015). Concentrated sugarcane juice containing 44\% (w/w) sucrose, $6 \%(\mathrm{w} / \mathrm{w})$ glucose and $5 \%(w / w)$ fructose was obtained from a sugarcane mill (São Paulo, Brazil). Before use, it was diluted $~ 10$-fold with water and supplemented with CSL (10 to $50 \mathrm{~g} / \mathrm{L})$ and MV $(350 \mu \mathrm{M})$. These media were sterilized by autoclaving at $121^{\circ} \mathrm{C}$ for $30 \mathrm{~min}$.

\subsection{Optimization of CSL concentration in batch fermentation} various amounts of CSL (0-50 g/L). Each bottle also contained $2 \mathrm{~g} \mathrm{CaCO}_{3}(40 \mathrm{~g} / \mathrm{L})$ to buffer the fermentation $\mathrm{pH}$ at $\sim 6.0$. These bottles were inoculated with a seed culture of 1-day old at a 
1 batch containing $\sim 40 \mathrm{~g} / \mathrm{L}$ sugar and then pulse feeding concentrated sucrose $(400 \mathrm{~g} / \mathrm{L})$ or

2 sugarcane juice into the bioreactor at $\sim 32 \mathrm{~h}$ when all sugar in the medium was about to deplete.

3 Samples were taken twice a day at regular intervals to monitor cell growth, substrates (sucrose,

4 fructose, and glucose) consumption, and products (butanol, butyrate, acetate and ethanol)

5 production. All batch fermentations were repeated at least once.

\subsection{Immobilized-cell fermentation in FBB}

7 To evaluate the long-term performance and strain stability, repeated-batch fermentations

8 with cells immobilized in a fibrous bed bioreactor (FBB) (Lu et al., 2012; Jiang et al., 2014)

9 were studied with sucrose and sugarcane juice, respectively, as carbon source and CSL as

10 nitrogen source. The FBB (250 mL working volume), made of a glass column packed with a

11 spirally wound cotton towel laminated with a stainless steel wire mesh as a spacer, was

12 connected to a 1-L spinner flask, equipped with $\mathrm{pH}$ and temperature control, through a

13 recirculation loop. The spinner flask containing $600 \mathrm{~mL}$ medium and the FBB were autoclaved

14 separately, aseptically connected after sterilization, and then purged with nitrogen for $\sim 30$ min.

15 To start the fermentation, a 24-h seed culture $(\sim 30 \mathrm{~mL})$ prepared in CGM was inoculated into the

16 spinner flask at a volume ratio of $5 \%$. After the cell density in the spinner flask had reached

$17 \mathrm{OD}_{600} 6.0$, cells were immobilized onto the fibrous matrix by pumping and re-circulating the

18 fermentation broth (with cells) through the FBB. After several hours when the cell density no

19 longer decreased, the fermentation broth was removed from the spinner flask and replaced with

20 fresh medium to start a new batch. The repeated batch fermentation was operated for a total of 10 
consecutive batches, each for $24 \mathrm{~h}$. Liquid samples were taken right after each medium change, at $12 \mathrm{~h}$ and at $24 \mathrm{~h}$ right before medium change.

\subsection{Analytical methods}

Cells density, measured as the optical density at $600 \mathrm{~nm}\left(\mathrm{OD}_{600}\right)$, in fermentation broth was analyzed with a spectrophotometer. The specific growth rate $(\mu)$ in batch fermentation was calculated based on the $\mathrm{OD}_{600}$ data in the exponential growth phase. Sucrose, glucose and fructose were determined by high performance liquid chromatography using a carbohydrate analysis column (Transgenomic, CARBOSep CHO-882) at $80^{\circ} \mathrm{C}$ and water as the mobile phase at the flow rate of $0.5 \mathrm{~mL} / \mathrm{min}$. Acetate, butyrate, butanol, and ethanol were determined by gas chromatography (GC) as described previously (Jiang et al., 2014).

\section{Results and discussion}

\subsection{Optimization of CSL concentration in batch fermentation}

(1)

CSL, a byproduct of corn wet-milling, is rich in soluble proteins, amino acids, vitamins and minerals, and has been widely used as a cheap nitrogen source and nutritional supplement in industrial fermentations. Its use in clostridial fermentations improved performance by stimulating cell growth and metabolism (Choi et al., 2013; Saxena and Tanner, 2012; Wischral et al., 2016), but the supplementation level would depend on the type of substrate and microorganism used in the fermentation and must be optimized. In this study, the feasibility and optimal concentration of CSL as a low-cost nitrogen and nutrient source replacing more expensive yeast extract and tryptone were studied in serum bottles with sucrose and sugarcane 
juice, respectively, as the substrate. Figure 1 shows the effect of CSL on butanol production

2 from sucrose after 6-day fermentation (with about $84 \%$ of sucrose consumed). As expected,

3 increasing the CSL concentration from $10 \mathrm{~g} / \mathrm{L}$ to $40 \mathrm{~g} / \mathrm{L}$ in the sucrose medium also increased

4 butanol production from $9.5 \mathrm{~g} / \mathrm{L}$ to $11.7 \mathrm{~g} / \mathrm{L}$, with the corresponding butanol yield of 0.18 to 0.23

$5 \mathrm{~g} / \mathrm{g}$ and productivity of 0.07 to $0.08 \mathrm{~g} / \mathrm{L} \cdot \mathrm{h}$ (Fig. 1A). Further increasing the CSL concentration to

$6 \quad 50 \mathrm{~g} / \mathrm{L}$ did not improve butanol production, but decreased it to $10.8 \mathrm{~g} / \mathrm{L}$ at a slightly lower yield

7 of $0.21 \mathrm{~g} / \mathrm{g}$. In general, butyrate production decreased slightly from 7.7 to $6.9 \mathrm{~g} / \mathrm{L}$ with increasing

8 the CSL concentration from $10 \mathrm{~g} / \mathrm{L}$ to $50 \mathrm{~g} / \mathrm{L}$. Only small amounts of acetate and ethanol, less

9 than $0.5 \mathrm{~g} / \mathrm{L}$, were produced in these fermentations. However, when sugarcane juice, which

10 already contained some nitrogen sources and minerals to support good cell growth (de Souza et

11 al., 2015; Sikder et al., 2012; Wei et al., 2017), was used as the substrate, only $10 \mathrm{~g} / \mathrm{L}$ of CSL

12 was needed to increase butanol production to $11.7 \mathrm{~g} / \mathrm{L}$ (vs. $9.9 \mathrm{~g} / \mathrm{L}$ for the control without CSL

13 addition) with a butanol yield of $0.23 \mathrm{~g} / \mathrm{g}$, while further increasing CSL supplementation showed

14 no beneficial effect (Fig. 1B). Butyrate production increased from $4.7 \mathrm{~g} / \mathrm{L}$ without CSL to $5.5 \mathrm{~g} / \mathrm{L}$

15 with $10 \mathrm{~g} / \mathrm{L} \mathrm{CSL}$ and $5.9 \mathrm{~g} / \mathrm{L}$ with $50 \mathrm{~g} / \mathrm{L} \mathrm{CSL}$. The optimal level of CSL supplementation was

16 thus determined to be $40 \mathrm{~g} / \mathrm{L}$ for sucrose and $10 \mathrm{~g} / \mathrm{L}$ for sugarcane juice, respectively, as substrate

17 in the fermentation medium.

\subsection{Free-cell fermentations in stirred-tank bioreactor}

19 Free-cell fermentations with sucrose and sugarcane juice as the substrate, respectively,

20 supplemented with CSL as the nitrogen source were studied in stirred-tank bioreactors. Figure 2 
shows the kinetics with the sucrose medium in batch and fed-batch fermentations. About 16.0 $\mathrm{g} / \mathrm{L}$ butanol, $3.6 \mathrm{~g} / \mathrm{L}$ butyrate, $1.4 \mathrm{~g} / \mathrm{L}$ acetate and $1.2 \mathrm{~g} / \mathrm{L}$ ethanol were produced from $\sim 53.3 \mathrm{~g}$ sucrose consumed in $48 \mathrm{~h}$ in the batch fermentation (Fig. 2A). Similar amounts of butanol, ethanol and acetate but slightly more butyrate $(5.0 \mathrm{~g} / \mathrm{L})$ were produced from sucrose in the

fed-batch fermentation, which stopped at $56 \mathrm{~h}$ with $\sim 21.0 \mathrm{~g} / \mathrm{L}$ sucrose unused (Fig. 2B), probably because of butanol inhibition (Zhao et al., 2013). The butanol yield and productivity obtained in these fermentations were $0.31 \pm 0.02 \mathrm{~g} / \mathrm{g}$ and $0.33 \pm 0.02 \mathrm{~g} / \mathrm{L} \cdot \mathrm{h}$, respectively.

Similar kinetics was obtained with sugarcane juice, which contained mainly sucrose and also small amounts of glucose and fructose. As shown in Figure 3, all three sugars were used simultaneously in the fermentation by $\mathrm{Ct}(\Delta \mathrm{ack})$-pscrBAK, indicating no glucose-mediated carbon catabolite repression (CCR) in the fermentation (Görke and Stülke, 2008; Yao and Shimizu, 2013). About $15.0 \mathrm{~g} / \mathrm{L}$ butanol, $4.7 \mathrm{~g} / \mathrm{L}$ butyrate, $1.4 \mathrm{~g} / \mathrm{L}$ acetate and $1.1 \mathrm{~g} / \mathrm{L}$ ethanol were produced in these fermentations, with the corresponding butanol yield and productivity of $0.24 \pm 0.02 \mathrm{~g} / \mathrm{g}$ and $0.30 \pm 0.02 \mathrm{~g} / \mathrm{L} \cdot \mathrm{h}$, respectively, which were slightly lower than those obtained in the fermentations with sucrose. It is also noted that the specific growth rate for cells grown in sugarcane juice $\left(0.071 \pm 0.008 \mathrm{~h}^{-1}\right)$ was also slightly lower than that $\left(0.077 \pm 0.014 \mathrm{~h}^{-1}\right)$ in the sucrose medium. The lower specific growth rate and butanol productivity and yield could be attributed to the lower amount of CSL $(10 \mathrm{~g} / \mathrm{L}$ vs. $40 \mathrm{~g} / \mathrm{L})$ used in sugarcane juice fermentation and also possibly to inhibitors generated through caramelization or Maillard reaction and heavy metals (Xia et al., 2016) present in the concentrated sugarcane juice, which was obtained from fresh sugarcane juice after evaporation. 
For comparison, fermentations with sucrose and sugarcane juice, respectively, as the carbon source were also conducted in CGM with yeast extract $(2 \mathrm{~g} / \mathrm{L})$ and tryptone $(4 \mathrm{~g} / \mathrm{L})$ as nitrogen sources, which gave much higher specific growth rates $(\mu)$ with significantly higher acids production but lower butanol production (Table 1). In general, yeast extract and tryptone supported faster cell growth $\left(\mu=0.11-0.15 \mathrm{~h}^{-1}\right.$ vs. $0.071-0.077 \mathrm{~h}^{-1}$ with CSL) but at the expense of lower butanol productivity $(0.21-0.28 \mathrm{~g} / \mathrm{L} \cdot \mathrm{h}$ vs. $0.30-0.33 \mathrm{~g} / \mathrm{L} \cdot \mathrm{h}$ with CSL) and yield (0.20-0.25 g/g vs. $0.24-0.31 \mathrm{~g} / \mathrm{L} \cdot \mathrm{h}$ with CSL) due to more substrate carbon used for acids biosynthesis (butyrate: $~ 10.7$ vs. $\sim 4.5 \mathrm{~g} / \mathrm{L}$ with CSL; acetate: $\sim 2.5$ vs. $\sim 1.42 \mathrm{~g} / \mathrm{L}$ with CSL). It can be concluded that CSL is a better nitrogen source than yeast extract and tryptone for butanol production from sucrose and sugarcane juice by $C$. tyrobutyricum $\mathrm{Ct}(\Delta \mathrm{ack})-\operatorname{pscrBAK}$.

\subsection{Immobilized-cell fermentation in the FBB}

Repeated batch fermentations with cells immobilized in the FBB were studied to evaluate the long-term performance and stability of $\mathrm{Ct}(\Delta \mathrm{ack})$-pscrBAK, and the results are shown in Figures $\mathbf{4}$ and $\mathbf{5}$ for fermentations with sucrose and sugarcane juice, respectively. In general, stable and consistent butanol production at $\sim 12 \mathrm{~g} / \mathrm{L}$ and butanol yield of $0.21 \pm 0.02 \mathrm{~g} / \mathrm{g}$ were obtained in these repeated batches, except for the first batch for reactor start up, 4th batch in the sucrose fermentation due to an operational issue, and 6th batch in the sugarcane juice fermentation. Overall, butanol productivity in these repeated batches was $0.47 \pm 0.03 \mathrm{~g} / \mathrm{L} \cdot \mathrm{h}$ in the sucrose fermentation and $0.53 \pm 0.05 \mathrm{~g} / \mathrm{L} \cdot \mathrm{h}$ in sugarcane juice, which were $42.4 \%-76.7 \%$ higher than those observed in free-cell fermentations, which could be attributed to higher cell 
1 density and tolerance to butanol cytotoxicity in the FBB (Huang et al., 2004; Jiang et al., 2014).

2 It should be noted that the butanol productivity was $13 \%$ higher with sugarcane juice than with

3 sucrose in the FBB while $10 \%$ lower butanol productivity was obtained with sugarcane juice in

4 free-cell fermentation, suggesting that cells immobilized in the FBB had better tolerance to

5 inhibitors present in the concentrated sugarcane juice. Better cell tolerance to butanol and other

6 inhibitors can be attributed to cell adaptation and physiological changes induced by the FBB

7 environment, as previously reported for $n$-butanol (Huang et al., 2004; Jiang et al., 2014; Lu et

8 al., 2012) and butyric acid fermentations (Zhu and Yang, 2003). The FBB fermentation results

9 also confirmed that $\mathrm{Ct}(\Delta \mathrm{ack})$-pscrBAK was robust and genetically stable, even without applying

10 antibiotic as the selection pressure for the recombinant plasmid, for butanol production from

11 sucrose and sugarcane juice.

\subsection{Comparison to other studies}

$\mathrm{Ct}(\Delta \mathrm{ack})$-pscrBAK overexpressing $a d h E 2$ and three $s c r$ operon genes ( $\operatorname{scr} B, s c r A$, and $s c r K)$ was able to produce butanol from sucrose present in sugarcane juice at a high productivity of

$15 \quad 0.30 \mathrm{~g} / \mathrm{L} \cdot \mathrm{h}$ in free-cell fermentation and $0.53 \mathrm{~g} / \mathrm{L} \cdot \mathrm{h}$ in the $\mathrm{FBB}$, which were $15 \%-56 \%$ higher than those in similar fermentations with C. acetobutylicum JB200 (Jiang et al., 2014), probably

17 because the latter was subject to glucose repression. Glucose and fructose present in sugarcane

18 juice and molasses are the preferred substrates over sucrose and can cause CCR in common

19 solventogenic clostridia including C. acetobutylicum and C. beijerinckii (Reid et al., 1999;

20 Tangney and Mitchell, 2000). It should be noted that there were few studies on the analysis of 
sucrose metabolism in clostridia (Tangney and Mitchell, 2000; Reid et al, 1999) and E. coli

2 (Sabri et al., 2013). To date, most of the glucose CCR studies have focused on its effects on

3 xylose utilization and strategies to overcome the CCR in fermentation with glucose and xylose as

4 co-substrates (Gawand et al., 2013; Matsuoka and Shimizu, 2013; Wei et al., 2016; Yu et al.,

5 2015b). The work reported in this study was the first demonstrating the use of heterologous scr

6 genes to enable sucrose utilization in a bacterium (C. tyrobutyricum) without being subject to

7 CCR.

8

9

$\mathrm{Ct}(\Delta$ ack)-pscrBAK also compared favorably to other solventogenic strains, including $C$. acetobutylicum ATCC 824 (Kittithanesuan and Phisalaphong, 2015), C. beijerinckii NCP P260

(Shaheen et al., 2000) and C. saccharobutylicum DSM 13864 (Ni et al., 2012), which produced butanol from sugarcane juice or cane molasses at a lower titer of $12-15 \mathrm{~g} / \mathrm{L}$ due to lower butanol tolerance (see Table 2). Furthermore, $\mathrm{Ct}(\Delta a c k)$-pscrBAK produced $n$-butanol as the main product and only a small amount of ethanol and no acetone, which would be much easier for butanol to be separated and purified in downstream processing, offering another advantage over conventional ABE fermentation (Du et al., 2015).

It should be noted that the performance of sucrose fermentation by $\mathrm{Ct}(\Delta a c k)$-pscrBAK also compared favorably to other engineered strains of $C$. tyrobutyricum in using different low-cost substrates, including $\mathrm{Ct}(\Delta$ ack)-pGluI with maltose and soluble starch (Yu et al., 2015a) and $\mathrm{Ct}(\Delta \mathrm{ack})$-pTBA with glucose and xylose present in soybean hull hydrolysate (Yu et al., 2015b) (see Table 2). Since sucrose and sucrose-based feedstock are cheaper than glucose and starch-based substrates (Jiang et al., 2014) and cellulosic feedstocks are difficult and expensive 
1 to be hydrolyzed to fermentable sugars (Jang et al., 2012; Wang et al., 2014), using

$2 \mathrm{Ct}(\Delta \mathrm{ack})$-pscrBAK to ferment sugarcane juice supplemented with CSL should provide an

3 economically viable and competitive process for industrial biobutanol production.

\section{4. Conclusions}

5 C. tyrobutyricum $\mathrm{Ct}(\Delta \mathrm{ack})$-pscrBAK was engineered to express $s c r B, s c r A$, and $s c r K$ for

6 sucrose catabolism and $a d h E 2$ for butanol biosynthesis. The engineered strain was able to use

7 sucrose simultaneously with glucose and fructose present in sugarcane juice without subjecting

8 to CCR. The fermentation of sugarcane juice supplemented with corn steep liquor (CSL) by

$9 \mathrm{Ct}(\Delta \mathrm{ack})$-pscrBAK gave a high butanol titer, yield and productivity, providing an economically

10 viable process for biobutanol production.

\section{Acknowledgements}

12 Financial support from the National Science Foundation STTR program (IIP-1026648) and

13 China Scholarship Council for research visit of Zhang (201406350172) at OSU are

14 acknowledged. 


\section{References}

1. Bellido, C., Infante, C., Coca, M., Gonzalez-Benito, G., Lucas, S., Garcia-Cubero, M.T. 2015. Efficient acetone-butanol-ethanol production by Clostridium beijerinckii from sugar beet pulp. Bioresour. Technol. 190, 332-338.

2. Cho, C., Jang, Y.S., Moon, H.G, Lee, J., Lee, S.Y. 2015. Metabolic engineering of clostridia for the production of chemicals. Biofuels. Bioprod. Biorefin. 9, 211-225.

3. Choi, J.D.R., Jang, Y.S., Cho, J.H., Seung, D., Lee, S.Y., Papoutsakis, E.T., Bennett, G.N., Song, H. 2013. Characterization and evaluation of corn steep liquid in acetone-butanol-ethanol production by Clostridium acetobutylicum. Biotechnol. Bioprocess. 18, 266-271.

4. de Souza, R.B., de Menezes, J.A.S., de Souza, R. de F.R., Dutra, E.D., de Morais, M.A. 2015. Mineral composition of the sugarcane juice and its influence on the ethanol fermentation. Appl. Biochem. Biotechnol. 175, 209-222.

5. Du, Y.M., Jiang, W.Y., Yu, M.R., Tang, I.C., Yang, S.T. 2015. Metabolic process engineering of Clostridium tyrobutyricum $\Delta$ ack-adhE2 for enhanced n-butanol production from glucose: Effects of methyl viologen on NADH availability, flux distribution, and fermentation kinetics. Biotechnol. Bioeng. 112, 705-715.

6. Filho, M.V., Araujo, C., Bonfa, A., Porto, W., 2011. Chemistry based on renewable raw materials: perspectives for a sugar cane-based biorefinery. Enzyme Res., 2011, 654596. doi: $10.4061 / 2011 / 654596$

7. Gawand, P., Hyland, P., Ekins, A., Martin, V.J.J., Mahadevan, R. 2013. Novel approach to engineer strains for simultaneous sugar utilization. Metab. Eng. 20, 63-72.

8. Görke, B., Stülke, J. 2008. Carbon catabolite repression in bacteria: many ways to make the most out of nutrients. Nat. Rev. Microbiol., 6, 613-624.

9. Green, E.M. 2011. Fermentative production of butanol-the industrial perspective. Curr. Opin. Biotechnol. 22, 337-343.

10. Huang, W.C., Ramey, D.E., Yang, S.T. 2004. Continuous production of butanol by Clostridium acetobutylicum immobilized in a fibrous bed bioreactor. Appl. Biochem. Biotechnol. 113-116, 
887-898.

11. Jang, YS., Malaviya, A., Cho, C., Lee, J., Lee, S.Y. 2012. Butanol production from renewable biomass by clostridia. Bioresour. Technol. 123, 653-663.

12. Jiang, W.Y., Zhao, J.B., Wang, Z.Q., Yang, S.T. 2014. Stable high-titer n-butanol production from sucrose and sugarcane juice by Clostridium acetobutylicum JB200 in repeated batch fermentations. Bioresour. Technol. 163, 172-179.

13. Kittithanesuan, N., Phisalaphong, M. 2015. Enhanced acetone-butanol production from sugarcane juice by immobilized Clostridium acetobutylicum (ATCC 824) on thin-shell silk cocoons. Biotechnol. Bioproc. Eng. 20, 599-607.

14. Kumar, G., Sen, B., Lin, C. Y., 2013a. Pretreatment and hydrolysis methods for recovery of fermentable sugars from de-oiled Jatropha waste. Bioresour. Technol. 145, 275-279.

15. Kumar, M., Goyal, Y., Sarkar, A., Gayen, K. 2013b. Comparative economic assessment of ABE fermentation based on cellulosic and non-cellulosic feedstocks. Appl. Energy 93, 193-204.

16. Lee, J., Jang, Y., Han, M.-J., Kim, J.Y., Lee, S.Y. 2016. Deciphering Clostridium tyrobutyricum metabolism based on the whole-genome sequence and proteome analyses. mBio 7(3), e00743-16.

17. Liu, K., Atiyeh, H.K., Pardo-Planas, O., Ezeji, T.C., Ujor, V., Overton, J.C., Berning, K., Wilkins, Mark, R., Tanner, R.S., 2015. Butanol production from hydrothermolysis-pretreated switchgrass: Quantification of inhibitors and detoxification of hydrolysate. Bioresour. Technol. 189, 292-301.

18. Liu, X., Zhu, Y., Yang, S.T. 2006. Construction and characterization of ack deleted mutant of Clostridium tyrobutyricum for enhanced butyric acid and hydrogen production. Biotechnol. Progr. 22, $1265-1275$.

19. Lu, C., Zhao, J., Yang, S.T., Wei, D., 2012. Fed-batch fermentation for n-butanol production from cassava bagasse hydrolysate in a fibrous bed bioreactor with continuous gas stripping. Bioresour. Technol. 104, 380-387.

20. Lu, C., Dong, J., Yang, S.T., 2013. Butanol production from wood pulping hydrolysate in an integrated fermentation-gas stripping process. Bioresour. Technol. 143, 467-475.

21. Lütke-Eversloh, T. 2014. Application of new metabolic engineering tools for Clostridium 
acetobutylicum. Appl. Microbiol. Biotechnol. 98, 5823-5837.

22. Matsuoka, Y., Shimizu, K, 2013. Catabolite regulation analysis of Escherichia coli for acetate overflow mechanism and co-consumption of multiple sugars based on systems biology approach using computer simulation. J. Biotechnol. 168, 155-173.

23. Mariano, A.P., Dias, M.O., Junqueira, T.L., Cunha, M.P., Bonomi, A., Filho, R.M. 2013. Butanol production in a first-generation Brazilian sugarcane biorefinery: technical aspects and economics of greenfield projects. Bioresour. Technol. 135, 316-323.

24. Ni, Y., Wang, Y., Sun, Z.H. 2012. Butanol Production from cane molasses by Clostridium saccharobutylicum DSM 13864: Batch and semicontinuous fermentation. Appl. Biochem. Biotechnol. 166, 1896-1907.

25. Reid, S.J., Rafudeen, M.S., Leat, N.G. 1999. The genes controlling sucrose utilisation in Clostridium beijerinckii 8052 constitutes an operon. Microbiology 145, 1461-1472.

26. Sabri, S., Nielsen, L.K., Ce, V. 2013. Molecular control of sucrose utilization in Escherichia coli W, an efficient sucrose-utilizing strain. Appl. Environ. Microbiol. 79, 478-487.

27. Saxena, J., Tanner, R.S. 2012. Optimization of a corn steep medium for production of ethanol from synthesis gas fermentation by Clostridium ragsdalei. World. J. Microb. Biothnol. 28, 1553-1561.

28. Shaheen, R., Shirley, M., Jones, D.T. 2000. Comparative fermentation studies of industrial strains belonging to four species of solvent-producing clostridia. J. Mol. Microbiol. Biotechnol. 2, 115-124.

29. Shao, M.X., Chen, H.Z. 2015. Feasibility of acetone-butanol-ethanol (ABE) fermentation from Amorphophallus konjac waste by Clostridium acetobutylicum ATCC 824. Process Biochem. 50, 1301-1307.

30. Sikder, J., Roy, M., Dey, P., Pal, P., 2012. Techno-economic analysis of a membrane-integrated bioreactor system for production of lactic acid from sugarcane juice. Biochem. Eng. J., 63, 81-87.

31. Tangney, M., Mitchell, W.J. 2000. Analysis of a catabolic operon for sucrose transport and metabolism in Clostridium acetobutylicum ATCC 824. J. Mol. Microbiol. Biotechnol. 2, 71-80.

32. Wang, J., Yang, X., Chen, C.C., Yang, S.T. 2014. Engineering clostridia for butanol production from biorenewable resources: from cells to process integration. Curr. Opin. Chem. Eng. 6, 43-54. 
33. Wei, P., Lin, M., Wang, Z., Fu, H., Yang, H., Jiang, W., Yang, S.T. 2016. Metabolic engineering of Propionibacterium freudenreichii subsp. shermanii for xylose fermentation, Bioresour. Technol., 219, 91-97.

34. Wei, P., Cheng, C., Lin, M., Zhou,Y., Yang, S.T. 2017. Production of poly(malic acid) from sugarcane juice in fermentation by Aureobasidium pullulans: Kinetics and process economics. Bioresour. Technol. 224, 581-589.

35. Wischral, D., Zhang, J.Z., Cheng, C., Lin, M., De Souza, L.M.G., Pessoa, F.L.P., Pereira, N., Yang, S. T. 2016. Production of 1,3-propanediol by Clostridium beijerinckii DSM 791 from crude glycerol and corn steep liquor: Process optimization and metabolic engineering. Bioresour. Technol. 212, $100-110$.

36. Xia, J., Xu, J., Hu, L. and Liu. X., 2016. Enhanced poly(L-malic acid) production from pretreated cane molasses by Aureobasidium pullulans in fed-batch fermentation. Prep. Biochem. Biotechnol. 46, 798-802.

37. Xu, M., Zhao, J., Yu, L., Tang, I.C., Xue, C., Yang, S.T. 2015. Engineering Clostridium acetobutylicum with a histidine kinase knockout for enhanced $n$-butanol tolerance and production. Appl. Microbiol. Biotechnol. 99, 1011-1022.

38. Xue, C., Zhao, J.B., Lu, C.C., Yang, S.T., Bai, F.W., Tang, I.C. 2012. High-titer n-butanol production by Clostridium acetobutylicum JB200 in fed-batch fermentation with intermittent gas stripping. Biotechnol. Bioeng. 109, 2746-2756.

39. Xue, C., Zhao, J.B., Liu, F., Lu, C.C., Yang, S.T., Bai, F.W. 2013. Two-stage in situ gas stripping for enhanced butanol fermentation and energy-saving product recovery. Bioresour. Technol. 135, $396-402$.

40. Xue, C., Zhao, J.B., Chen, L.J., Bai, F.W., Yang, S.T., Sun, J.X., 2014. Integrated butanol recovery for an advanced biofuel: current state and prospects. Appl. Microbiol. Biotechnol., 98, 3463-3474.

41. Xue, C., Liu, F., Xu, M., Tang, I.C., Zhao, J.B., Bai, F.W., Yang, S.T. 2016. Butanol production in acetone-butanol-ethanol fermentation with in situ product recovery by adsorption. Bioresour. Technol. 219, 158-168. 
42. Yang, X., Xu, M., Yang, S.T. 2015. Metabolic and process engineering of Clostridium cellulovorans for biofuel production from cellulose, Metab, Eng., 32, 39-48.

43. Yao, R., Shimizu, K. 2013. Recent progress in metabolic engineering for the production of biofuels and biochemicals from renewable sources with particular emphasis on catabolite regulation and its modulation. Process Biochem. 48, 1409-1417.

44. Yu, M., Zhang, Y., Tang, I.C., Yang, S.T. 2011. Metabolic engineering of Clostridium tyrobutyricum for n-butanol production. Metab. Eng. 13, 373-82.

45. Yu, M., Du, Y., Jiang, W., Chang, W.L., Yang, S.T., Tang, I.C. 2012. Effects of different replicons in conjugative plasmids on transformation efficiency, plasmid stability, gene expression and n-butanol biosynthesis in Clostridium tyrobutyricum. Appl. Microbiol. Biotechnol. 93, 881-889.

46. Yu, L., Xu, M., Tang, I.C., Yang, S.T. 2015a. Metabolic engineering of Clostridium tyrobutyricum for n-butanol production from maltose and soluble starch by overexpressing alpha-glucosidase. Appl Biochem. Biotechnol. 99, 6155-65.

47. Yu, L., Xu, M., Tang, I.C., Yang, S.T. 2015b. Metabolic engineering of Clostridium tyrobutyricum for n-butanol production through co-utilization of glucose and xylose. Biotechnol. Bioeng. 112, $2134-41$.

48. Zhao, J., Lu, C., Chen, C.C., Yang, S.T. 2013. Biological production of butanol and higher alcohols, in Yang, S.T., El-Enshasy, H.A., Thongchul, N. (eds.) Bioprocessing Technologies in Biorefinery for Sustainable Production of Fuels, Chemicals, and Polymers, Wiley, Hoboken, NJ, Ch. 13, pp. $235-261$.

49. Zheng, J., Tashiro, Y., Wang, Q.H., Sonomoto, K. 2015. Recent advances to improve fermentative butanol production: Genetic engineering and fermentation technology. J. Biosci. Bioeng, 119, 1-9.

50. Zhu, Y., Yang, S.T. 2003. Adaptation of Clostridium tyrobutyricum for enhanced tolerance to butyric acid in a fibrous-bed bioreactor. Biotechnol. Progr. 19, 365-372. 
Table 1. Kinetics of free-cell fermentation of $\mathrm{Ct}(\Delta a c k)$-pscrBAK with sucrose or sugarcane juice as carbon source and CSL or YE and Tryp as nitrogen source.

\begin{tabular}{lccccccc}
\hline $\begin{array}{l}\text { Carbon / } \\
\text { Nitrogen source }\end{array}$ & $\begin{array}{c}\mu \\
\left(\mathrm{h}^{-1}\right)\end{array}$ & $\begin{array}{c}\text { Butanol } \\
(\mathrm{g} / \mathrm{L})\end{array}$ & $\begin{array}{c}\text { Butanol } \\
\text { Yield }(\mathrm{g} / \mathrm{g})\end{array}$ & $\begin{array}{c}\text { Productivity } \\
(\mathrm{g} / \mathrm{L} \cdot \mathrm{h})\end{array}$ & $\begin{array}{c}\text { Butyrate } \\
(\mathrm{g} / \mathrm{L})\end{array}$ & $\begin{array}{c}\text { Acetate } \\
(\mathrm{g} / \mathrm{L})\end{array}$ & $\begin{array}{c}\text { Ethanol } \\
(\mathrm{g} / \mathrm{L})\end{array}$ \\
\hline Sucrose & & & & & & & \\
CSL 40 & $0.077 \pm 0.014$ & $16.0 \pm 0.2$ & $0.31 \pm 0.02$ & $0.33 \pm 0.02$ & $4.3 \pm 0.7$ & $1.5 \pm 0.1$ & $1.1 \pm 0.2$ \\
YE 2, Tryp 4 & $0.15 \pm 0.02$ & $16.1 \pm 1.1$ & $0.25 \pm 0.02$ & $0.28 \pm 0.02$ & $10.2 \pm 1.5$ & $2.5 \pm 0.3$ & $1.3 \pm 0.0$ \\
Sugarcane juice & & & & & & & \\
CSL 10 & $0.071 \pm 0.008$ & $15.0 \pm 0.7$ & $0.24 \pm 0.02$ & $0.30 \pm 0.02$ & $4.7 \pm 0.2$ & $1.4 \pm 0.2$ & $1.1 \pm 0.1$ \\
YE 2, Tryp 4 & $0.11 \pm 0.02$ & $11.9 \pm 0.4$ & $0.20 \pm 0.03$ & $0.21 \pm 0.01$ & $11.2 \pm 1.2$ & $2.6 \pm 0.3$ & $1.1 \pm 0.2$ \\
\hline
\end{tabular}

CSL: corn steep liquor, g/L; YE: yeast extract, g/L; Tryp: tryptone, g/L. 
Table 2. Comparison of $\mathrm{Ct}(\Delta a c k)$-pscrBAK with other solventogenic clostridia strains for butanol production

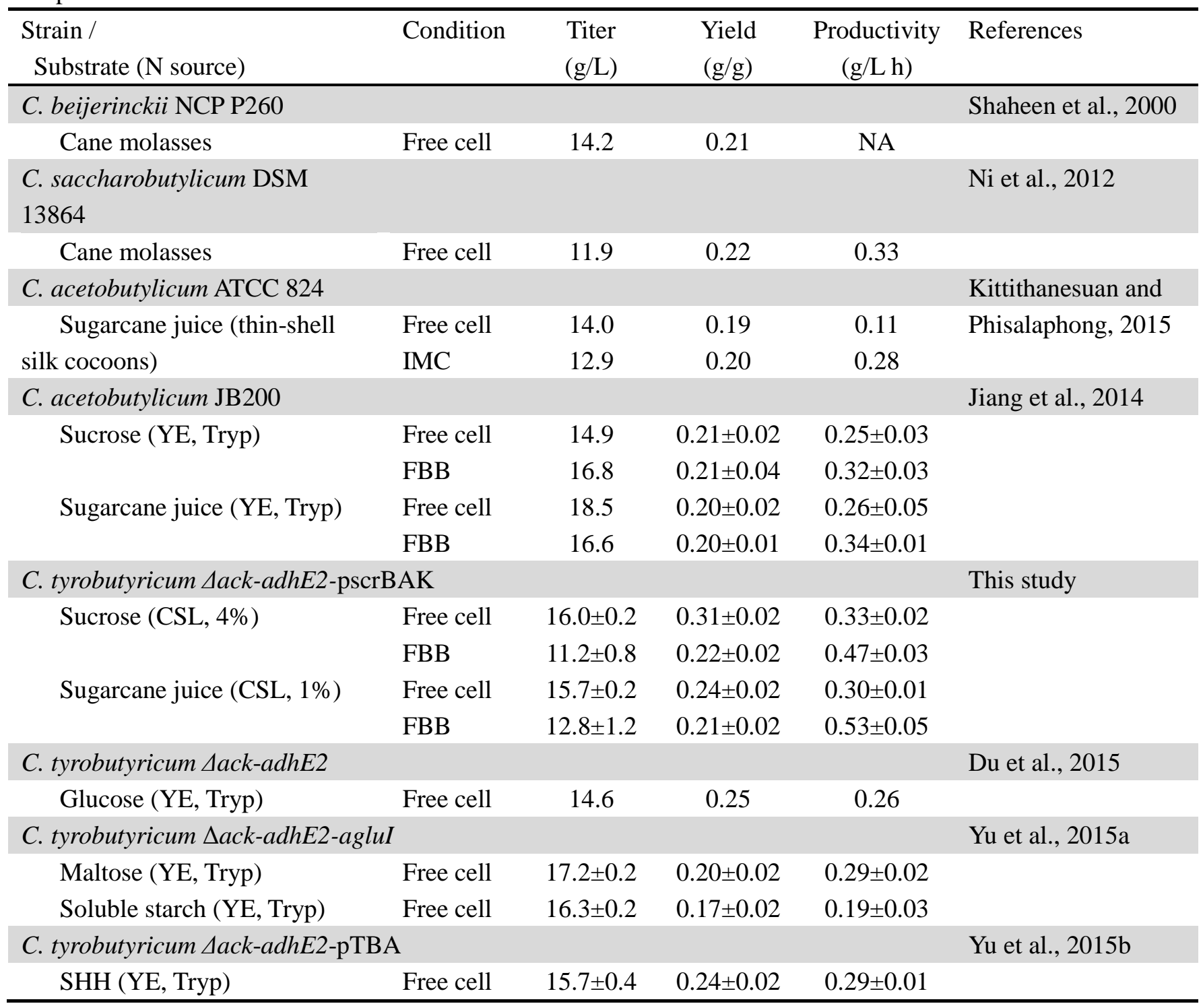

FBB: fibrous bed bioreactor; IMC: immobilized cell; NA: not available; SHH: soybean hull hydrolysate containing $45 \mathrm{~g} / \mathrm{L}$ glucose and $45 \mathrm{~g} / \mathrm{L}$ xylose 


\section{List of Figures}

Figure 1. Effects of CSL on fermentation kinetics of C. tyrobutyricum $\mathrm{Ct}(\Delta \mathrm{ack})$-pscrBAK grown on sucrose (A) and sugarcane juice (B) in serum bottles with $40 \mathrm{~g} / \mathrm{L} \mathrm{CaCO} 3,350 \mu \mathrm{M} \mathrm{MV}$, and no thiamphenicol. Acetate and ethanol were less than $0.5 \mathrm{~g} / \mathrm{L}$ (data not shown). Average values with standard deviations indicated by error bars from two independent bottles are shown.

Figure 2. Kinetics of free-cell fermentations of sucrose by C. tyrobutyricum $\mathrm{Ct}(\Delta \mathrm{ack})$-pscrBAK in stirred-tank bioreactors at $\mathrm{pH} 6.0$ and $37^{\circ} \mathrm{C}$. The medium also contained $40 \mathrm{~g} / \mathrm{L} \mathrm{CSL}$ and 350 $\mu \mathrm{M}$ MV, but no thiamphenicol. A. Batch fermentation; B. Fed-batch fermentation.

Figure 3. Kinetics of free-cell fermentations of sugarcane juice by C. tyrobutyricum $\mathrm{Ct}(\Delta \mathrm{ack})-\mathrm{pscrBAK}$ in stirred-tank bioreactors at $\mathrm{pH} 6.0$ and $37^{\circ} \mathrm{C}$. The medium also contained $10 \mathrm{~g} / \mathrm{L} \mathrm{CSL}$ and $350 \mu \mathrm{M} \mathrm{MV}$, but no thiamphenicol. A. Batch fermentation; B. Fed-batch fermentation.

Figure 4. Repeated batch fermentations of sucrose by C. tyrobutyricum $\mathrm{Ct}(\Delta \mathrm{ack})$-pscrBAK immobilized in a FBB. The media also contained $40 \mathrm{~g} / \mathrm{L}$ CSL and $350 \mu \mathrm{M}$ MV but no thiamphenicol. A. Time course profiles of sucrose and products in the fermentation medium; B. butanol yield and productivity.

Figure 5 Repeated batch fermentations of sugarcane juice by $C$. tyrobutyricum $\mathrm{Ct}(\Delta$ ack)-pscrBAK immobilized in a FBB. The media also contained $10 \mathrm{~g} / \mathrm{L} \mathrm{CSL}$ and $350 \mu \mathrm{M}$ MV but no thiamphenicol. A. Time course profiles of sugars and products in the fermentation medium; B. butanol yield and productivity. 


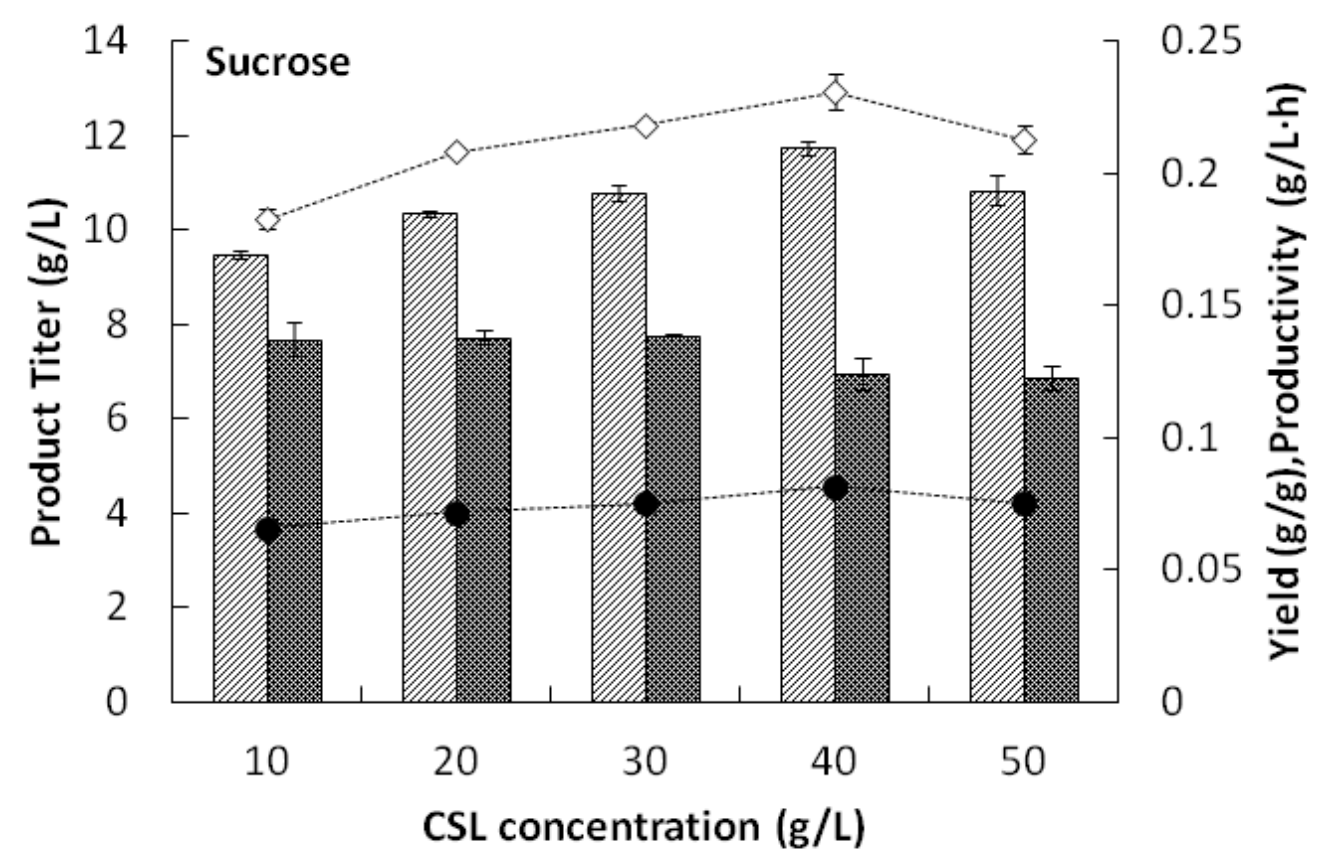

A

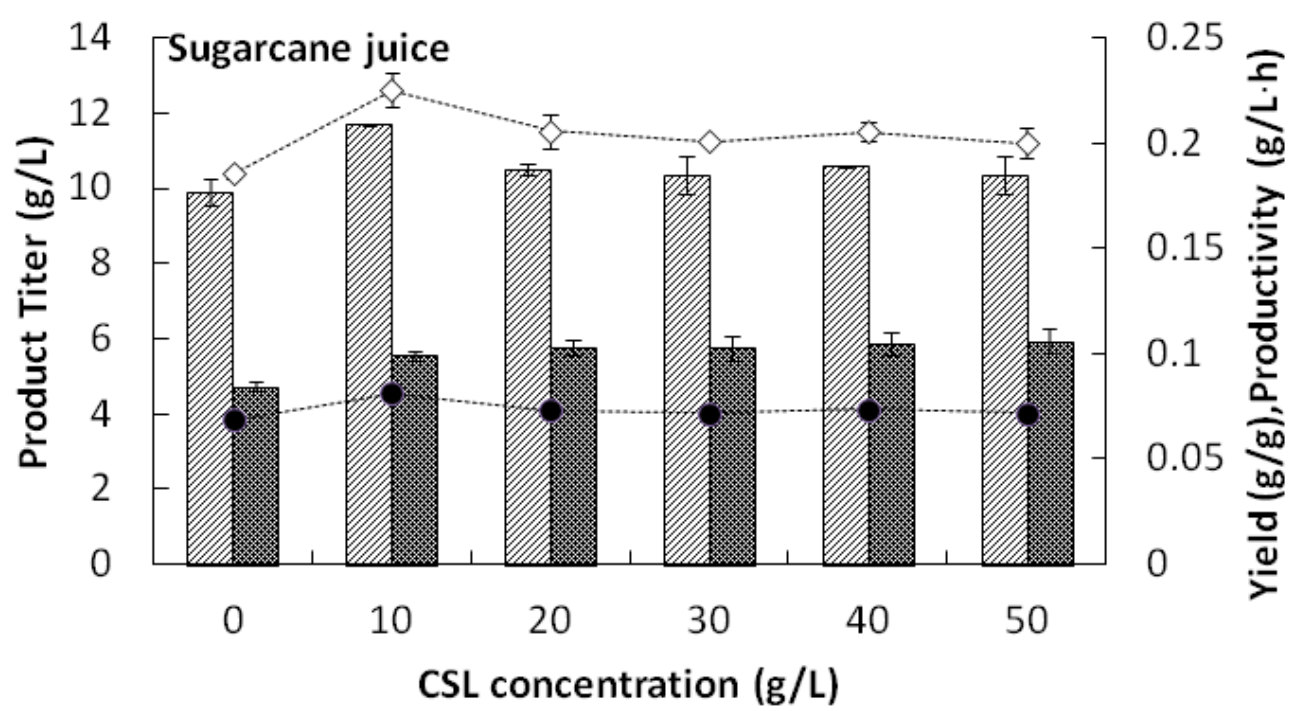

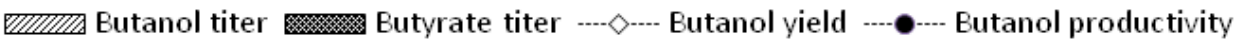

B

Figure 1 


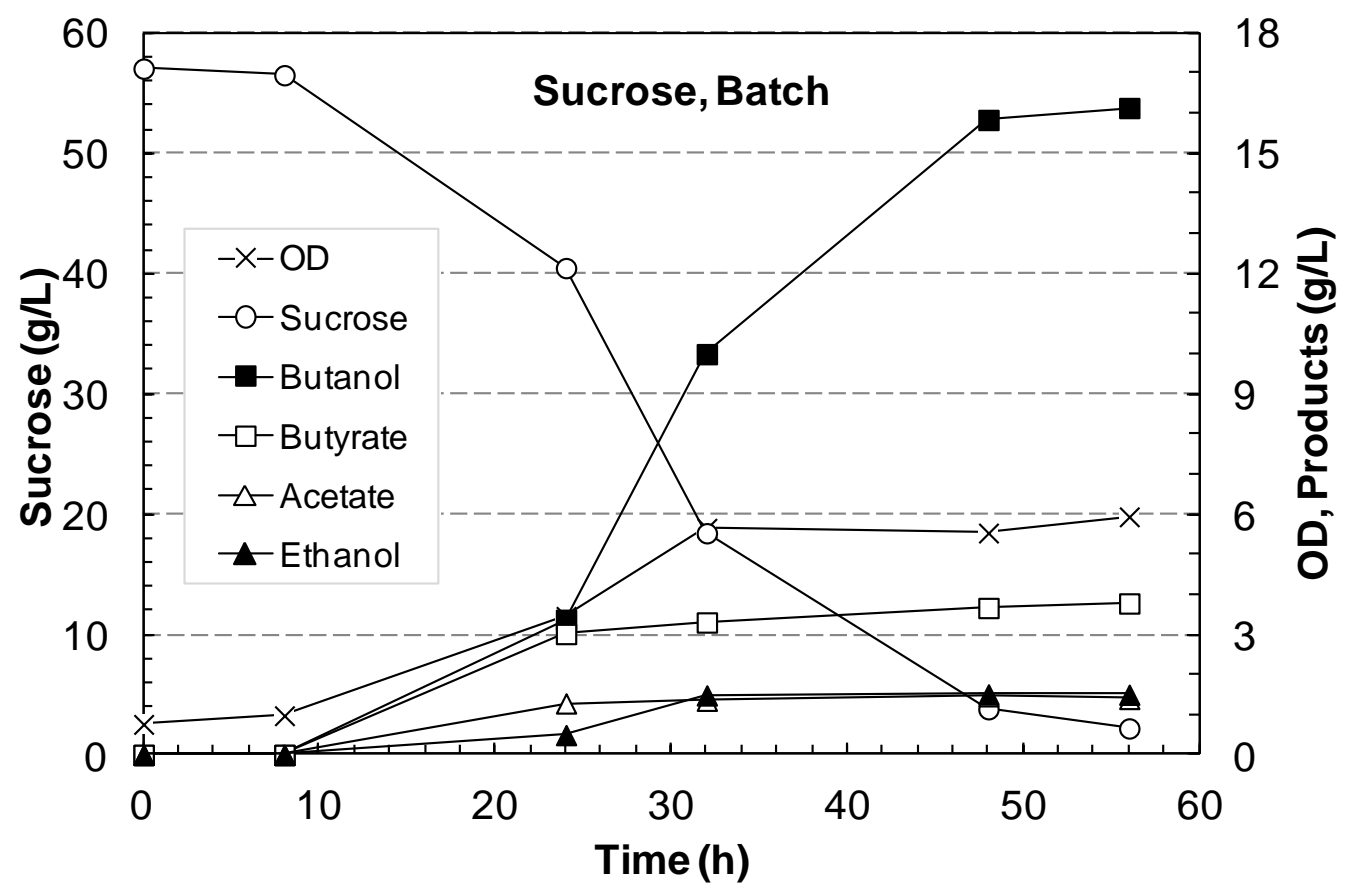

A

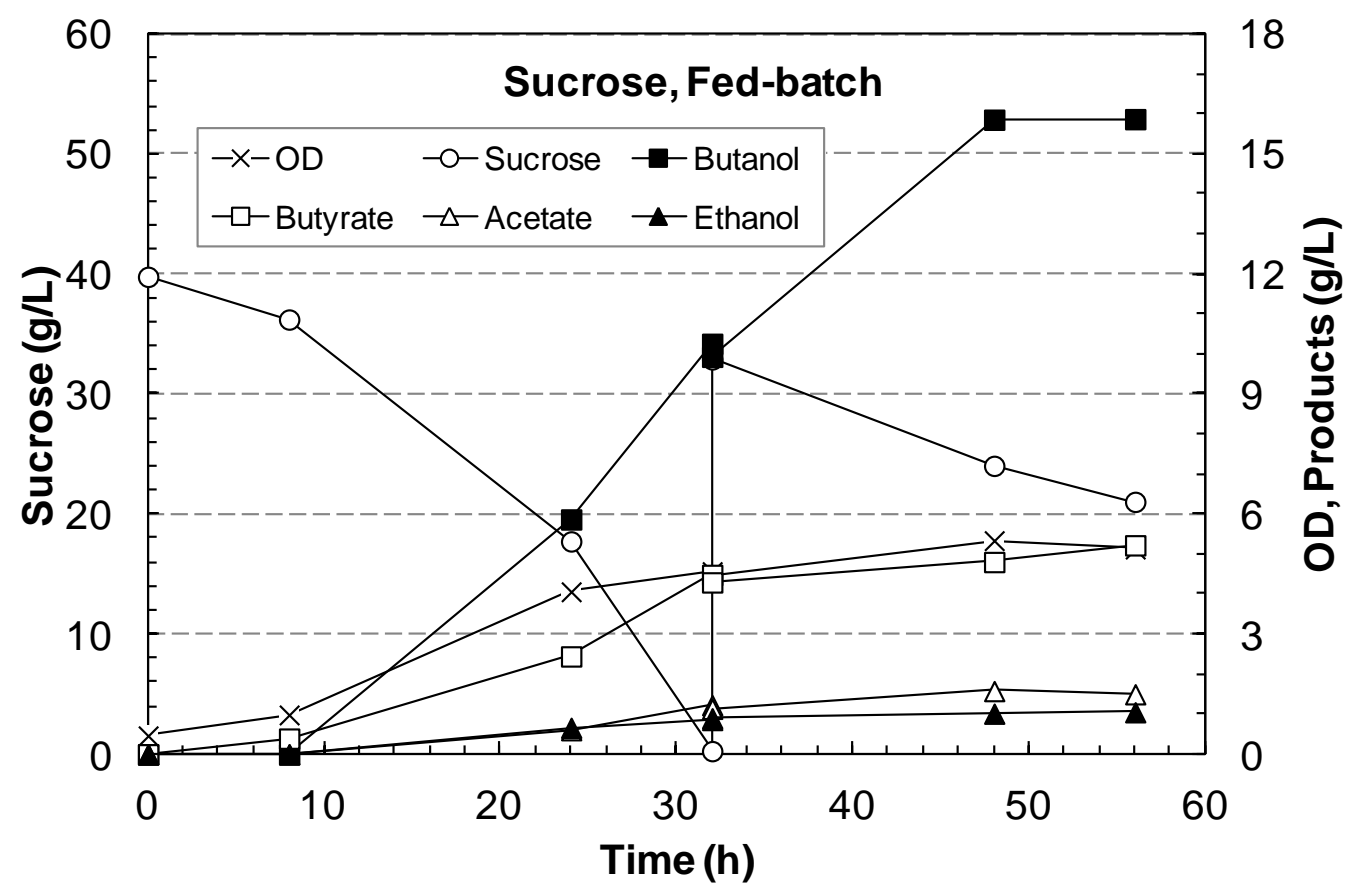

Figure 2 


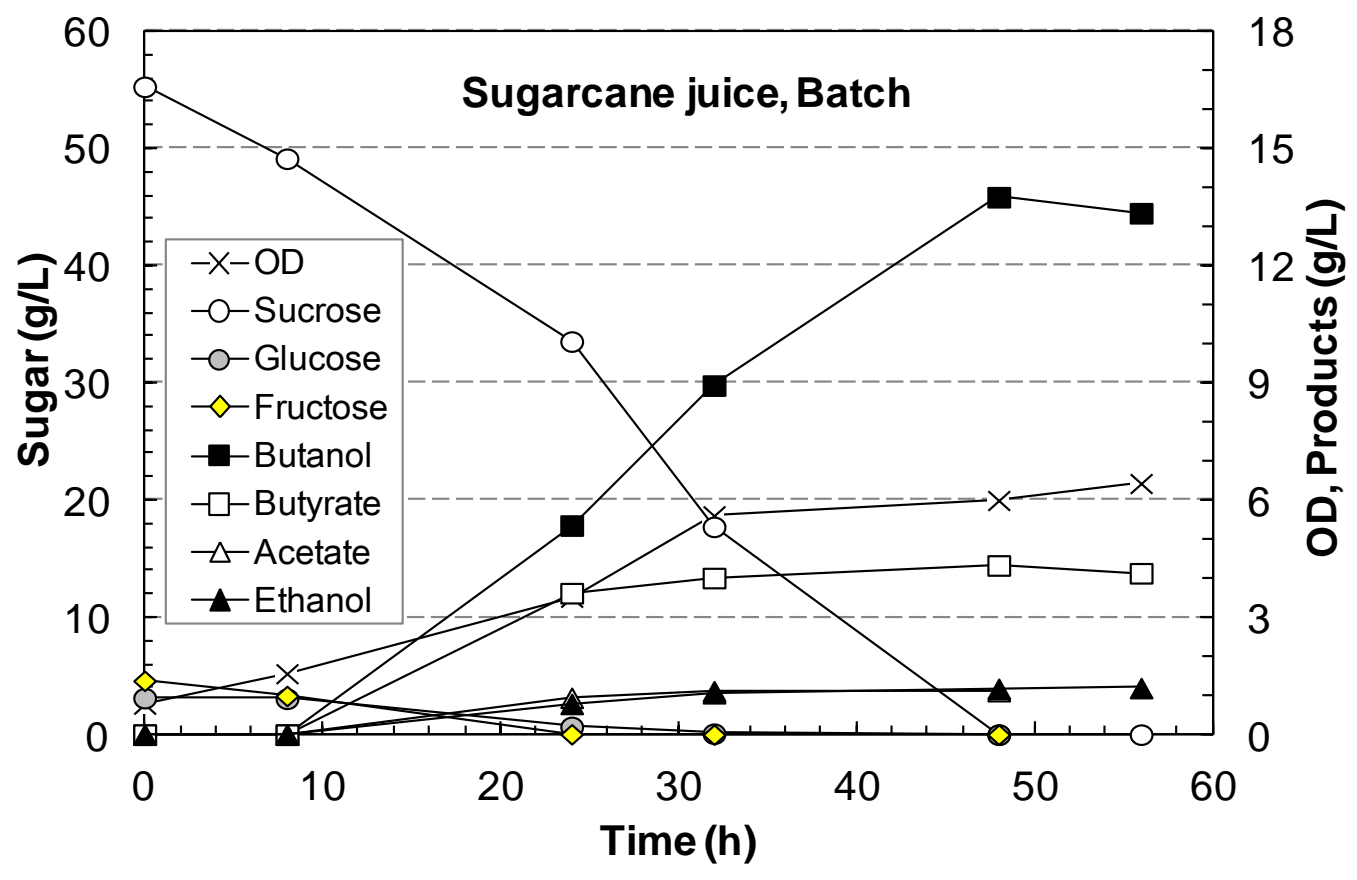

A

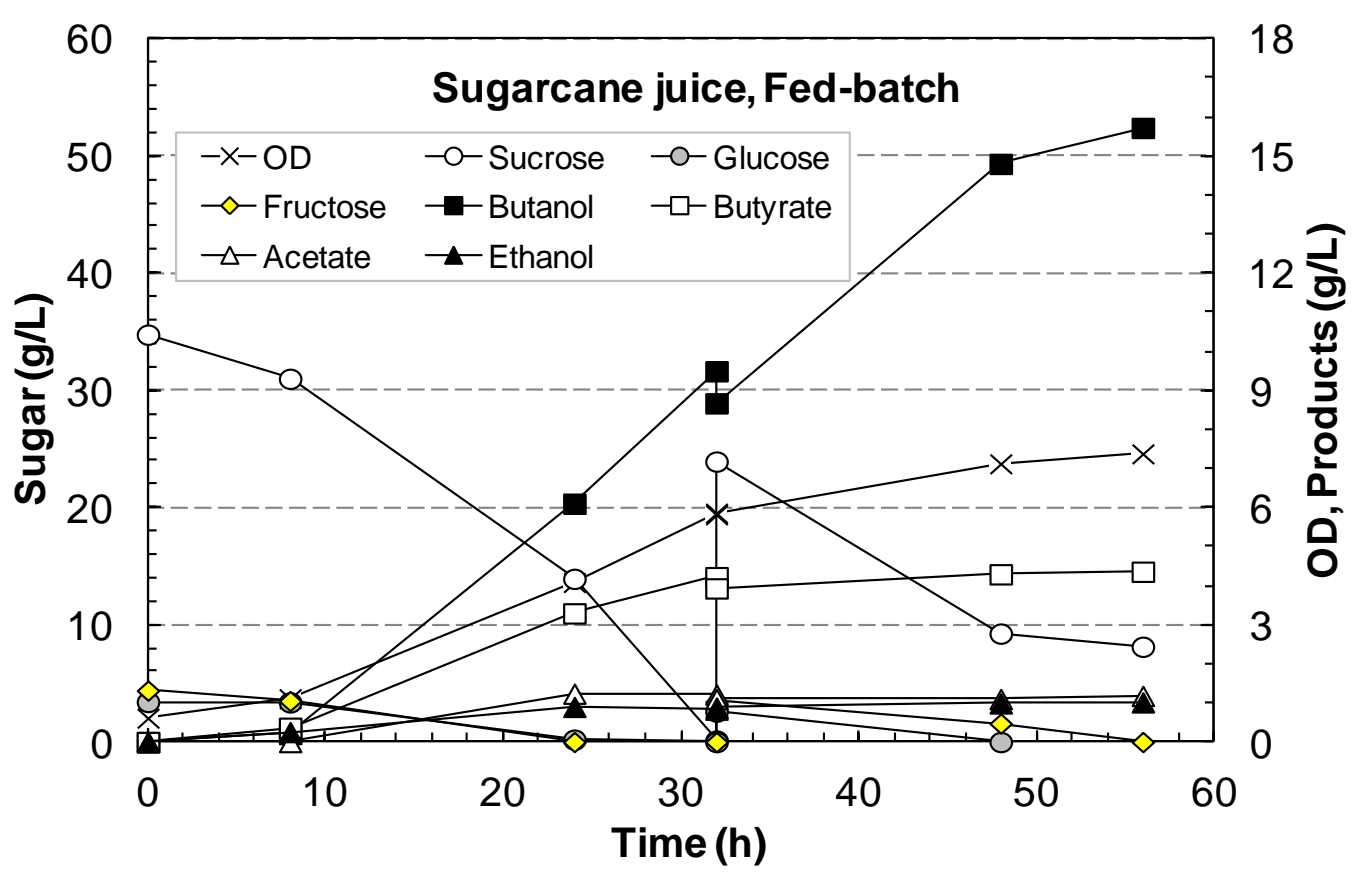

Figure 3 

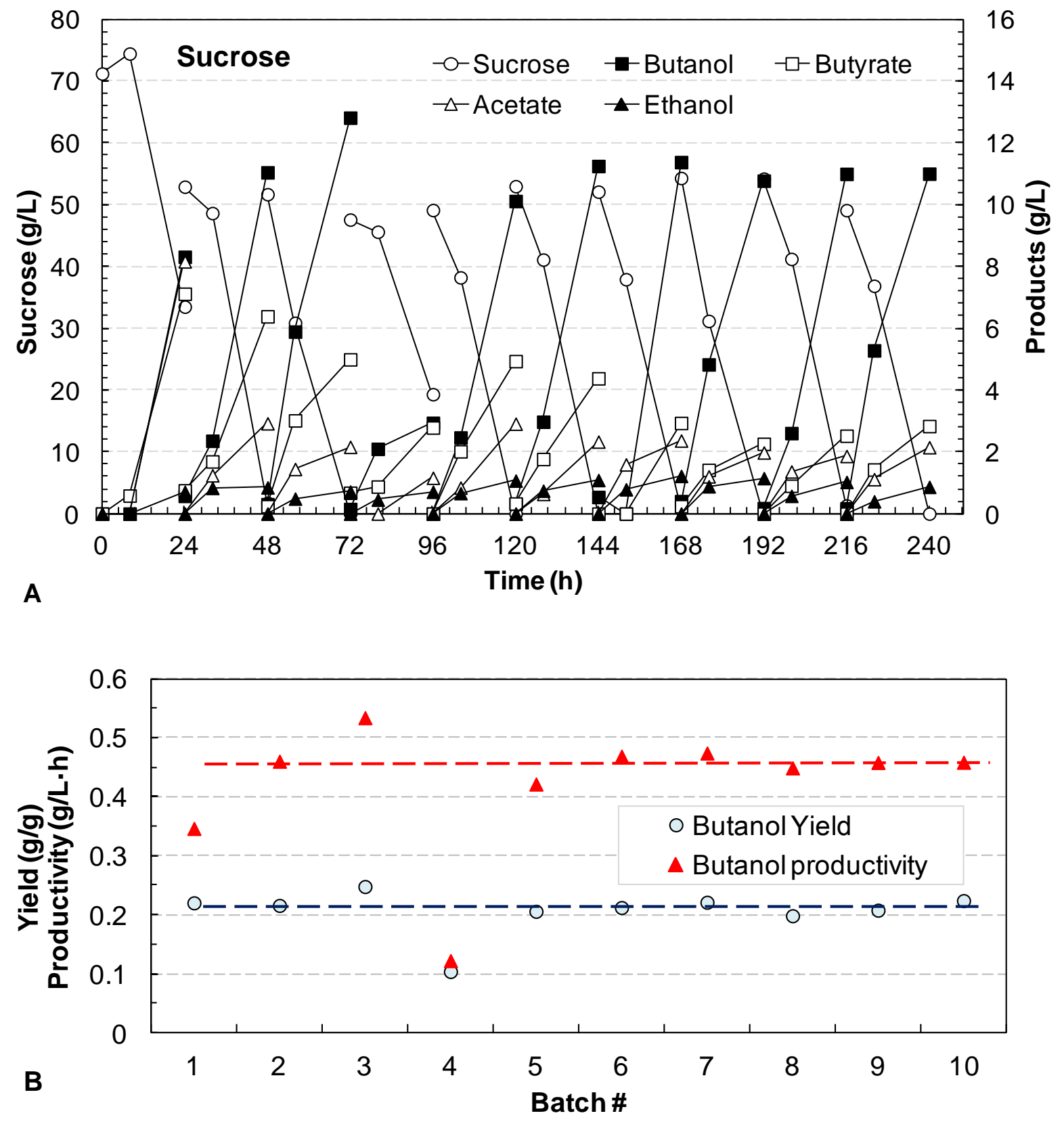

Figure 4 

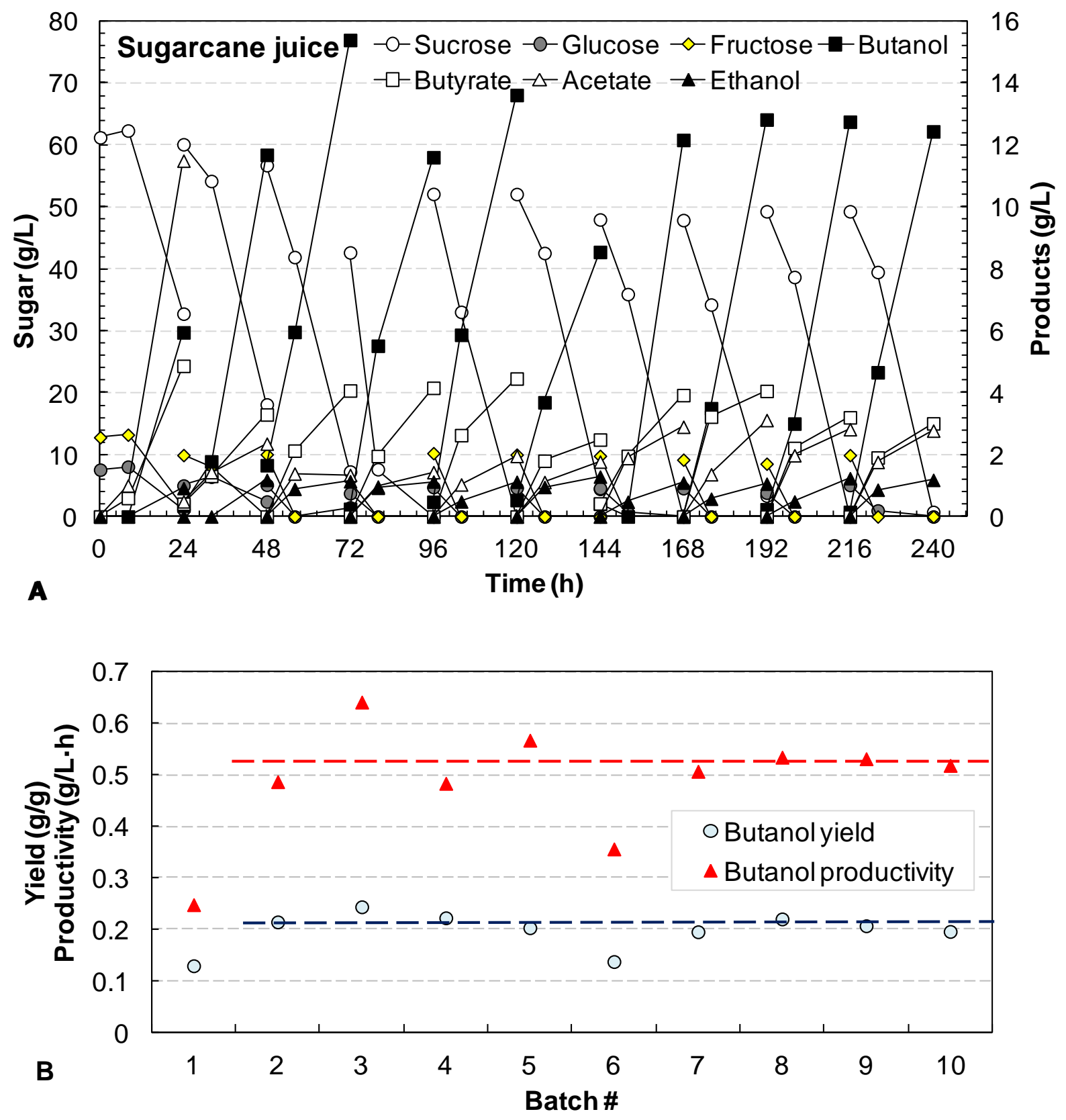

Figure 5 


\section{Graphical Abstract}

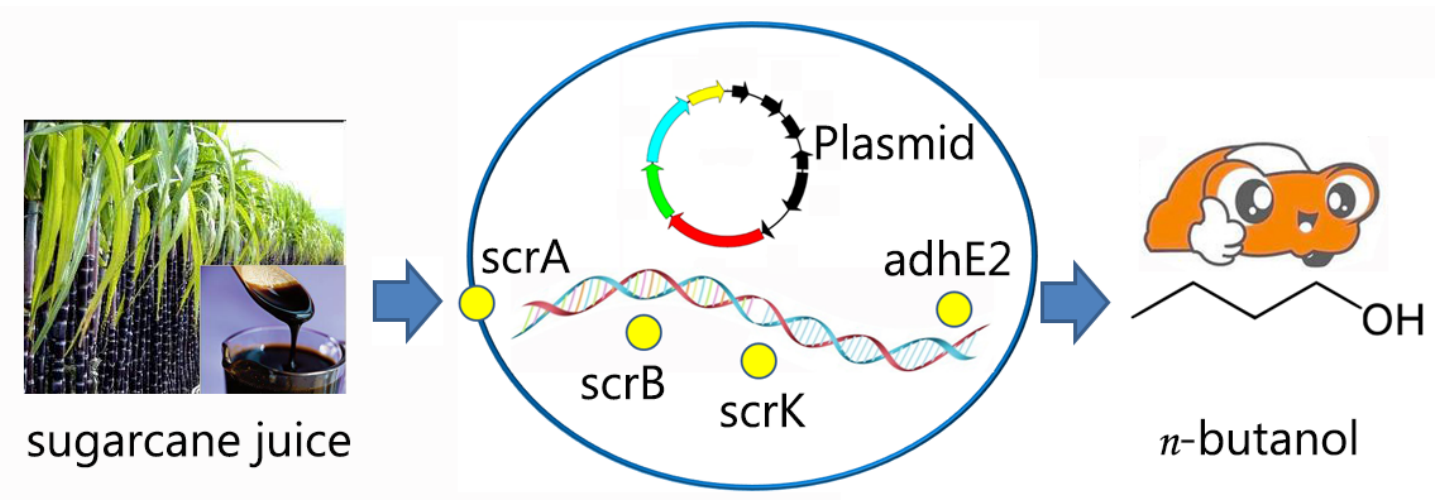

